\title{
5 \\ Natural knowledge in the New Atlantis
}

\author{
RICHARD SERJEANTSON
}

The End of our Foundation is the knowledge of Causes, and secret motions of things; and the enlarging of the bounds of Human Empire, to the effecting of all things possible.

And amongst them we have a water which we call Water of Paradise, being, by that we do to it, made very sovereign for health, and prolongation of life. ${ }^{\mathrm{I}}$

\section{Francis Bacon and early modern 'science'}

At the heart of Francis Bacon's New Atlantis there is an institution for the systematic pursuit of something that it is very tempting to call 'science'. In Salomon's House there are instruments for generating heat and sound, 'engine-houses' for producing motion, and 'perspective-houses' for demonstrating the effects of light. There are also 'shops' for making medicines, 'parks and inclosures' for observing and experimenting upon animals, orchards and gardens for cultivating crops, and 'bake-houses and kitchens' for making food and drink 'of special effects' (48o-6). And finally, Salomon's House has a permanent staff of fellows who carry out various specialised tasks, almost all of which involve 'experiments' in some way (486-7). The purpose of the institution is to produce knowledge (480); the kind of knowledge sought is, without exception, the knowledge of nature.

If Francis Bacon is famous for anything, it is for a singular concern with natural science. In a series of works, Bacon lambasted 
his contemporaries for their ignorance and complacency about the natural world, and proposed a series of increasingly bold plans to remedy the situation. In his grand encyclopaedia of human ignorance, The Advancement of Learning (1605), he anatomised the failings in the contemporary human understanding of the natural, human and divine worlds. As part of his vastly ambitious (and largely unfinished) programme of 'Great Renewal' (Instauratio magna), he elaborated in the New Instrument (Novum Organum) of I620 a general procedure for systematically investigating the natural world. And in the Sylva Sylvarum Bacon discussed a thousand different experiments on the natural world that he had either read about or done himself.

These and other works laid the foundation of Bacon's reputation. He was widely celebrated after his death for the power of his message about the importance of studying the natural world. From the middle years of the seventeenth century in England, through the eighteenth-century French encyclopédistes and nineteenth-century English Baconians like William Whewell, to twentieth-century scholarship, Bacon has been held up - with good cause - as one of the pre-eminent intellectual patrons of natural science. $^{2}$ The New Atlantis is an important document in this reception history, for it was often reprinted, was widely read, and indeed was sometimes even continued by other writers keen to exploit its ambitious, optimistic, but ultimately unfinished qualities.

Is 'science' in fact the best word, though, to describe Bacon's interests? It is certainly a convenient label, a useful shorthand that seems to cover in one term the whole range of the activities pursued in Salomon's House in the New Atlantis. But it is also an anachronistic word. 'Science', in the modern sense, did not exist when Bacon was writing: the categories of 'science' and the 'scientist' are creations of the nineteenth, not of the seventeenth century. ${ }^{3}$ Scholars in the past (even the recent past) have perhaps been a little too quick to see Bacon as a 'modern scientist', and indeed even to see the New Atlantis as a key text in 'the emergence of modern scientific practices from within late Renaissance culture'.$^{4}$ In order to avoid the problems with thinking of Bacon as someone who was writing about 'science', I prefer to talk in this essay about 'natural knowledge'. This, as it happens, is a fair enough translation of the Renaissance Latin term scientia naturalis. 
But it is also a good broad historical category for thinking about all the other ways in which the natural world was understood in the early seventeenth century - some of which are rather a long way from modern 'science'.

The reason we should be wary of looking at Bacon through modern conceptual spectacles is this: if we are too quick to call the concerns of the New Atlantis 'science', we may miss the significance of what is actually happening in the work. If we concentrate on Bacon in his capacity as a prophet of modern science, we may miss the importance of the medieval and Renaissance traditions of natural knowledge that suffuse his works. Indeed, this issue has produced polarised views about the New Atlantis. According to some writers, Bacon actually foresaw the industrial revolution - and all its problems - in his 'prophecy of modern science'.${ }^{5} \mathrm{Per}$ contra - according to Rosalie Colie - Bacon in fact took all of the 'tricks' in the New Atlantis from 'late medieval and Renaissance compendia of the natural sciences' ${ }^{6}$ We do not need to endorse the idea that Bacon had especially prophetic powers about the course of subsequent history. But we can nonetheless see that it might be possible both for him to have derived the ideas in Salomon's House from contemporary forms of natural knowledge, and then to have turned these materials into things quite novel and different. Later on in this essay, I shall show how this is so in the case of two forms of natural knowledge that Bacon takes up and develops in the New Atlantis: natural magic, and medicine.

\section{The works of nature}

We should begin, however, by surveying the range of natural knowledge evident in Salomon's House and assessing its significance. In his introduction to the New Atlantis, which he published after Bacon's death, Bacon's chaplain William Rawley described the purpose of the New Atlantis as 'the producing of great and marvellous works for the benefit of men' (785). The term 'works' holds the key to understanding the natural knowledge of the New Atlantis. The pursuits in Salomon's House are practical, not theoretical. Its experiments aim to do things to the natural world: to change it and to use it, not just to observe and understand it. Its fellows pride themselves on finding out about all the 
'manufactures, and inventions' of the world, as much as they do about finding out about its 'sciences, [and] arts' (47I).

This emphasis on practical knowledge - on making and doing as the best means of understanding the world - was central to Bacon's philosophy of science. ${ }^{7}$ It lay behind his scathing critique of the contemporary natural philosophy that he thought he found in the universities of late Renaissance Europe. This natural philosophy was a contemplative science; it sought knowledge of universal causes, rather than particular effects. It emphasised generalised 'experience' over particular 'experiment'. ${ }^{8}$ Even worse, to Bacon's mind, was that its preferred form of argument was the syllogism: this, he complained in the Instauratio magna, 'lets nature slip out of its hands'.$^{9}$ Instead, Bacon advocated understanding nature through its works. In the Novum Organum he listed the kinds of people who actually tackled nature in this way: mechanics, mathematical practitioners, medical doctors, alchemists, and magicians. But none of them, according to Bacon, had either tried very hard, or achieved very much. ${ }^{\text {10 }}$

Nonetheless, ideas from all of these occupations inform the New Atlantis. And for the past fifty years or so, scholars have tried to understand some of the ways in which this is so. Rosalie Colie, in particular, showed beautifully how some of the inventions of the New Atlantis were well known in early seventeenthcentury London. She explains how several of the experiments in the New Atlantis are reminiscent of the marvels exhibited to the court of King James I by the Dutch inventor Cornelis Drebbel. Like the experimenters of Salomon's House who use sunken caves for 'coagulations, indurations, refrigerations, and conservations of bodies' (480), Drebbel engaged in demonstrations involving heat and cold. He managed to chill the Great Hall at Westminster so thoroughly that it drove the King and his retinue away. He even built a remarkable submersible vessel in which he descended beneath the Thames for three hours in 1620 , in front of an audience that included James I and also the Dutch visitor Constantijn Huygens, who wrote a vivid account of the occasion. Bacon must have heard of this technological triumph - he was perhaps even present on the occasion - by the time he had the Father of Salomon's House state laconically that 'we have ships and boats for going under water' $(486) .{ }^{\text {II }}$ 
J. Peter Zetterberg developed Colie's study by discussing some English works that described artificial curiosities and wonders: books like William Bourne's Inventions and Devises (1578) and Thomas Tymme's A Dialogue Philosophicall (16r2), which partially translates Drebbel. Zetterberg emphasises the ways in which Bacon's New Atlantis picks up on a large literature - and a substantial body of practice - about ways of making art imitate nature. ${ }^{\mathrm{I} 2}$ This is an important insight into the significance of some of the activities of Bacon's contemporaries for the New Atlantis. But we should also not forget that the purpose of Salomon's House is 'enlarging the bounds of Human Empire'. Bacon is interested in more than imitating nature: he wants to 'conquer' it as well. ${ }^{13}$

Penelope Gouk, too, has argued that court masques elaborate one-off dramatic entertainments performed before the King - provided a model for the 'sound-houses' described in the New Atlantis. And she goes on to observe that Bacon's claims for what could be achieved in them were not fanciful, but rather 'embodied the achievements of contemporary musicians, artisans and engineers'. These achievements included producing sounds by means of air and water, after the manner of the ancient Greek mathematician Hero of Alexandria or - a more proximate model Salomon de Caus. ${ }^{14}$ In the same way, the fellows of Salomon's House 'represent and imitate all articulate sounds and letters, and the voices and notes of beasts and birds' (485). Other early modern natural philosophers were also interested in the relations between musical instruments, the language of animals, and human speech, and Bacon himself elsewhere discusses the possibility of artificially imitating human voices. ${ }^{15}$ The preoccupations of the New Atlantis are quite characteristic, in fact, of the widespread Renaissance quest to uncover the 'secrets of nature'. Indeed, one historian of this quest has suggested that a reason for the popularity of the New Atlantis in the seventeenth century was that it picks up to such a degree on the practical experimentalism in these 'books of secrets'. ${ }^{16}$

We should not imagine, however, that natural knowledge, for Bacon or his Bensalemites, is merely for human utility. ${ }^{17}$ It has at its heart a very much higher purpose: one that is suggested by the Governor of the Strangers' House when he explains that 
Salomon's House is dedicated 'to the study of the Works and Creatures of God' (47I). By studying nature, Bacon suggests, the inhabitants of the New Atlantis are also honouring the Creator. The Governor explains that 'in ancient records' Salomon's House is sometimes also called 'the College of the Six Days Works' after the six days of creation described at the beginning of the Book of Genesis. Pre-modern treatises of natural knowledge are sometimes even organised according to a 'hexameral' schema derived from the events of each of the six days. ${ }^{18}$ It was commonplace in the sixteenth and seventeenth centuries to speak of the two books of God: the Bible as the Book of Revelation, and the world as the Book of Nature. The existence of God could be read from both, and it was the task of natural philosophy to understand the second book, as it was that of theology to understand the first. ${ }^{19}$ In this way, then, the 'science' of the New Atlantis is also a kind of divine worship and, quite explicitly, a means of human betterment in repairing the damage caused by the Fall from Paradise - a Fall brought about by the same Adam and Eve whose pools are used to establish the physical health of prospective marriage partners in Bensalem (478). ${ }^{20}$

\section{Natural magic}

The 'works' of nature, then, were studied in the Renaissance in many different ways and for many different purposes. But there is one tradition of natural knowledge that the New Atlantis perhaps owes more to than any other: natural magic. It is important to realise that what was called natural magic in the Renaissance is a long way from what might now be understood as magic. The modern understanding of magic is closer to what in the Renaissance was called spiritual and demonic magic. This kind of magic invoked spirits to perform feats - often nefarious ones - that were 'against nature'. ${ }^{21}$ Natural magic was quite different. As its name suggests, it was concerned exclusively with natural, not with supernatural effects. Its proponents often described it as the 'active' part of natural knowledge, because it performed marvellous effects that could not be explained by human reason. They could not be explained because they were hidden or, in early modern terms, 'occult'. Natural magic had 
some fairly esoteric theoretical justifications involving occult sympathies between disparate objects - which Bacon rejected. ${ }^{22}$ In practice, though, natural magic was mostly concerned with producing wonderful, and in the terms of Renaissance natural philosophy, inexplicable, effects. And on account of its practical inclination, writers on natural magic sometimes described it as the 'pinnacle' of the natural sciences. ${ }^{23}$

Bacon was well acquainted with late Renaissance works on natural magic, and in particular with one of the most important of these, the Natural Magic (Magia naturalis, I558, I589) of the Neapolitan magus Giovan Battista della Porta. Scholars have long known that many of the experiments in Bacon's main work of natural history, the Sylva Sylvarum, are developed from those in della Porta, although in the final version of the work Bacon never deigns to mention the Italian by name. ${ }^{24}$ It is less often pointed out how many of Bacon's preoccupations in the New Atlantis are also staples of the natural magic tradition. ${ }^{25}$ Thus the fellows busy themselves not only in experimenting upon animals, but also breeding them to 'make them greater or taller' and 'more fruitful and bearing than their kind is' (482); experiments and tips for breeding fill the second book of della Porta's Natural Magic. Likewise, della Porta deals (in book eleven) with making perfumes and producing smells - just as they do in Salomon's House (485). Other interests, such as processes of distillation, were shared by Bacon, della Porta (book ten) and numerous other practical writers $(484)$.

In fact, it is Bacon himself who establishes explicitly the association between his own interests and the tradition of natural magic. In the course of an experiment on how to change the colour of bird feathers in the Sylva Sylvarum, Bacon makes the remarkable claim that the Sylva is, 'to speak properly', not just natural history but 'a high kind of natural magic': 'For it is not a description of nature only, but a breaking of nature into great and strange works'. ${ }^{26}$ This description would serve even more appropriately for the New Atlantis.

Bacon's interest in the tricks and striking effects of the natural magic tradition brought with it a problem, however. Many of these experiments were specifically intended to baffle and amaze those who saw them. It was this meretricious marvellousness that 
encouraged both fascination with and hostility to natural magic and wonders of all kinds in the Renaissance. ${ }^{27}$ It also meant that the problem of separating true miracles from false ones became a recurrent preoccupation of writers in the period. A common justification for studying natural philosophy and the mathematical sciences was that they helped 'discover impostures, and false miracles' ${ }^{28}$ Bacon felt this problem particularly strongly, as becomes clear from the New Atlantis. The very last experiments the Father of Salomon's House mentions are those carried out in the 'houses of deceits of the senses; where we represent all manner of feats of juggling, false apparitions, impostures and illusions'. He observes that they know how to accomplish so many things which 'induce admiration' that they could easily be put to bad uses. 'But we do hate all impostures and lies,' he goes on, which is why the fellows are sworn to exhibit their natural knowledge 'without all affectation of strangeness' (486).

In fact, Bacon has already illustrated this concern with distinguishing true from false miracles earlier on in the New Atlantis. We learn from the Governor of the Strangers' House that 'about twenty years after the ascension of our Saviour', the Bensalemites received the Bible in a cedar chest hidden in a great pillar of light out at sea. There was much 'wonder' among the people of the city of Renfusa at this 'marvellous sight'. But the person who decides that it is 'a true Miracle' is one of the fellows of Salomon's House, to whom it has been given 'to know thy [God's] works of creation, ... and to discern ... between divine miracles, works of nature, works of art, and impostures and illusions of all sorts'. After he has 'devoutly viewed and contemplated this pillar', this fellow is able to know that it is indeed a miracle and not a work of magic - or worse (464). The people of Bensalem become Christians because of their excellent understanding of nature; they are, in short, consummate natural theologians. ${ }^{29}$

\section{Medicine and hygiene}

The inhabitants of Bensalem, however, do not belabour their study of the Creator through his works. They are more immediately concerned with merely human means of bettering their lot. In this, they reflect Bacon's preoccupations, and in one respect 
especially: their cultivation of the art of medicine. As he grew older, Bacon became increasingly concerned with ways of escaping, or at least delaying, the clutches of mortality, and his interest in medical questions correspondingly grew. The section on medicine in the later Latin version of The Advancement of Learning (De augmentis scientiarum, I623) is substantially enlarged from the English version of eighteen years before (I605). Bacon also wrote at length elsewhere on matters of health, sickness and nutrition, mostly in his late natural histories: the Sylva Sylvarum, and the History of Life and Death (Historia vitae et mortis, 1623). These medical issues are a vital - but rather neglected - aspect of Bacon's interest in nature..$^{30}$ Moreover, his growing preoccupation with medicine emerges strongly in the late New Atlantis. The work as a whole manifests a deep interest in the central questions of Renaissance medicine: how to cure disease, how to preserve health, and - in particular - how to prolong life.

The importance of medicine and health for the New Atlantis is indicated throughout the work. The European visitors' exposure to the food, drink, and medicine of Bensalem is the most important way in which they appreciate their hosts' power over the natural world before the Father of Salomon's House finally begins his discourse. The only reason, in fact, that the visitors are allowed to land on Bensalem in the first place is that their sick 'were many, and in very ill case' (458). Despite - or rather because of - the charity the Bensalemites extend to the Europeans, they also show an extreme consciousness of the dangers of disease. The 'great person' who asks whether the visitors are Christians maintains a safe distance from the ship on the instructions of the city's Conservator of Health (an office found in Renaissance Italy, if not perhaps early modern London). ${ }^{3 \mathrm{I}}$ The notary who comes aboard the Europeans' ship uses an orangelike fruit '(as it seemeth) for a preservative against infection' (459) infection theories of disease were a recurrent preoccupation at the time. ${ }^{32}$ We hear about this fruit again later on, when the Europeans are told that it is 'an assured remedy for sickness taken at sea'. The Bensalemites have an excellent understanding of nursing and medicine. The infirmary is well maintained; the Europeans are dispensed 'small grey or whitish' pills to hasten their recovery (46I). The regime of the Strangers' House is so 
successful that in just three days the European visitors express 'joy of the amendment of our sick'. Indeed, so well do they become, and so quickly, that they imagine themselves 'cast into some divine pool of healing' - the sort of pool, in fact, that we subsequently learn the Bensalemites actually have $(462,482)$.

When we come to hear about Salomon's House proper, medical arts and instruments become even more prominent. In the Chambers of Health, the air is regulated to allow both for the 'cure of divers diseases' and for the 'preservation of health' (48I). There are baths which are used 'for the cure of diseases, and the restoring of man's body' (482). Many of the plants cultivated in Bensalem's gardens are not just larger and tastier than their European counterparts, but are also of 'medicinal use' - such as, presumably, the fruitarian antidote to sea-sickness (482). There are foods that can sustain long fasts or endow bodies with a hardness or strength far beyond the normal (483). The medicine shops of Bensalem exploit the full extent of the island's rich flora and fauna to produce a much 'greater variety' of medicines than 'you have in Europe' (483). ${ }^{33}$ And Salomon's House even has those 'healing pools' which - if not divine - are certainly efficacious 'for the cure of diseases, and the restoring of man's body from arefaction [i.e. desiccation]: and ... for the confirming of it in strength of sinews, vital parts, and the very juice and substance of the body' (482). Moreover, there are also less therapeutic investigations into physiology: the fellows 'find many strange effects' in living animals, such as keeping them alive even after various parts that European physicians take to be necessary to life have been removed (482). ${ }^{34}$

Many of these instances have their counterpart in Renaissance medical theories and practices. The composition of the air was indeed thought to be vital to both disease and cure. ${ }^{35}$ Balneology (bathing) had become an important form of medical research and practice by the late Renaissance, although typically Bacon thought it was not pursued thoroughly enough. ${ }^{36}$ The medical use of plants, and their cultivation in 'physic gardens', was practically universal by the later sixteenth century. Moreover, the New World had become an important source of new and powerful medical ingredients (materia medica) that had been unknown to the Renaissance's ancient authorities, such as 
Dioscorides. Finally, Bacon's interest in moving beyond gross anatomy to more profound physiological enquiry is paralleled by developments in later sixteenth- and earlier seventeenth-century medical research. ${ }^{37}$

But the area of medicine that Bacon develops most thoroughly in the New Atlantis is the realm of hygiene. Medicine in the Renaissance was often divided into two broad parts: the cure of disease - therapy - and the prevention of disease - hygiene. Unlike the various forms of therapy, hygiene dealt with ways of preserving health and prolonging life, rather than with dealing with diseases after they had appeared. ${ }^{38}$ Hygiene was the part of medicine that Bacon prized above all: he complained more than once in his later writings that modern physicians needlessly restricted themselves to 'humble cures', and so were 'honoured for necessity only'. Instead of this, he said, they should seek a nobler goal: not just curing diseases, but actively preventing them. ${ }^{39}$

In the Renaissance, one of the most important means of preventing disease was held to be diet. Many works were written that discussed the kinds of food useful for maintaining health, from the first book on ageing - Gabriele de Zerbi's Care of the Old (Gerontocomia, I489) - to Tobias Venner's treatise on the health value of the different kinds of English food: the Right Road to a Long Life (Via recta ad vitam longam, 1622). $4^{\circ}$ Bacon's Bensalemites, too, are much occupied by questions of diet. As well as orchards and fields, they have 'brewhouses, bake-houses, and kitchens', where they make drinks, breads, and foods that are 'rare and of special effects' (483). And the effects that the Father of Salomon's House describes are indeed remarkable: their drinks last for many years, and even replace solid food. Other drinks, extraordinarily, are so refined they can pass through the hand. They have breads baked with fish and meat that can of themselves provide enough nourishment for life - indeed, for a 'very long' life. And the food in the Strangers' House, as well as being good, is also varied and healthful; the drink, in particular, is 'wonderful pleasing and refreshing' (46r) - in sharp contrast to the dirty water and tepid 'small beer' that was the usual fare of most people in early modern England. ${ }^{4}$ 


\section{The prolongation of life}

The food and drink of Salomon's House are good at preserving health. ${ }^{4^{2}}$ But they are even better at achieving the other abiding goal of early modern medical hygiene: the prolongation of life. It is not too strong to say that, by the time he came to write the New Atlantis, Bacon had become obsessed by the problem of how to extend human life. He read widely in earlier literature on the subject, from Arnold of Villanova in the middle ages to Alvise Cornaro's immensely popular Treatise on the sober life (Trattato de la vita sobria, I558). ${ }^{43}$ Bacon collected a set of medical recipes with the title 'The Grains of Youth'; one of them is for 'Methusalem water'. ${ }^{44}$ Much of the manuscript treatise De vijs mortis ('On the Ways of Death', written in the I6ros), and the later History of Life and Death are devoted to the question of the prolongation of life..$^{45}$ Bacon added a substantial discussion of the failings of previous ideas about increasing human longevity to the Latin version of The Advancement of Learning, that has no precursor in the English text. ${ }^{6}$ As if to remind us how important it is for the New Atlantis, 'The prolongation of life' is the very first of the 'Wonderful works of nature' (Magnalia naturae) that are listed at the end of that work (488). So important did Bacon find the question of prolongation, in fact, that he assigned a whole department of medicine to the question, noting that it was 'new, and deficient; and the noblest of all' ${ }^{47}$

The Bensalemites of the New Atlantis are not deficient in ways of extending life. The experiments in Salomon's House return repeatedly to the issue. Among the first things we hear about it is that they use caverns 'for prolongation of life in some hermits that choose to live there', and who 'indeed live very long' (480). There is the bread which, as well as being able to sustain life 'without any other meat', also allows its eaters to 'live very long' (483). The Father of Salomon's House even speaks of 'a water, which we call Water of Paradise, being by that we do to it made very sovereign for health and prolongation of life' (48I).

Despite his own claims for it, however, it is hard to see Bacon's preoccupation with the prolongation of life as the 'new science', the terms in which so many commentators like to describe his interests. The Bensalemites' 'Water of Paradise', in fact, tastes 
suspiciously like Old World wine in New Atlantan bottles. Far from being a new pursuit, the quest for prolongation was as old as medieval alchemy, and several authors in that tradition had even discussed the possibility of an 'Elixir of Life' that would allow those who drank it vastly to extend their normal span..$^{8}$ Frequent suggestions were made about ingredients that might lengthen life, among the most common of which were 'potable gold' and precious stones. Bacon was not as scornful of these suggestions as he was about other suggested ingredients ambergris, vipers' flesh, stag marrow and 'the fume of youth' breathed from a young virgin. ${ }^{49} \mathrm{He}$ was a little more respectful of other theories based on the existence of a 'radical moisture' which dried up in the course of life and caused death when it was exhausted - but not much..$^{50}$ During the Renaissance, efforts to achieve the prolongation of life intensified..$^{51}$ One of the bestknown accounts was offered by the Italian neoplatonist Marsilio Ficino, in the second of his Three Books on Life (De vita triplici, I489). Among Ficino's many recommendations was that old men might restore their strength by sucking blood from the arm of a 'willing, happy, healthy, temperate' youth. Bacon knew this suggestion well - and rejected it, twice..$^{52} \mathrm{He}$ also rejected an idea developed by a follower of the medical radical, Paracelsus (I493I54I), who proposed that if we could somehow absorb the 'spirit' of living creatures, we would become immortal. 53

Thus Bacon's concern in the New Atlantis with food and drink as a means of prolongation is quite consistent with his comment in the History of Life and Death that properly prepared food and drink is much more important for preserving life than earlier physicians' 'fables' about ingesting gold or precious stones. Of the pretensions of astrologers to determine length of life by the stars, he was frankly scornful. Like Alvise Cornaro, although not to the same degree as him, Bacon considered diet, not elixirs or infusions, to be the key to long life. 'The curing of diseases', he wrote, 'is done by temporary medicines; but the prolongation of life must be sought through diets'. ${ }^{54}$

Despite his acquaintance with earlier writings on prolongation, however, Bacon had little time for their recommendations. In a typically inflated statement of his own novelty, he claimed to be the first to discuss the question of the prolongation of life 
solely as an aspect of medicine. ${ }^{55}$ Of other traditional determinants of longevity - sufficient sleep, or sexual moderation - Bacon had little to say. But we can find other elements in the New Atlantis that we know he believed conduced to longevity. He thought a religious life, perhaps like that lived by the hermits, was good (480). He thought island-dwellers lived longer than those on continents: Bensalem is an island, albeit a large one (469). He collected stories showing that cave-dwellers - like the hermits who live in the caverns of the Lower Regions (480-I) regularly reached great ages. And, in good Baconian fashion, Bacon thought he had proved from the historical examples of ancient natural philosophers that a life spent contemplating nature was a powerful way to prolong it; this describes exactly the fellows of Salomon's House. ${ }^{56}$

If Bacon's interest in the prolongation of life was a very traditional one, his proposals for achieving it were a little less so. He elaborated a detailed account of how 'arefaction' was one of the principal processes of physical decay. ${ }^{57} \mathrm{He}$ was also fascinated by the prospect of making food and drink that lasted a very long time - just like the Bensalemites (483). This was a problem he returned to repeatedly - and which, according to John Aubrey, eventually killed him: he reputedly caught a chill preserving a chicken in snow. ${ }^{5}$ The reason for this fascination was that Bacon believed the longer food was kept, the better it would be at prolonging life. The ideal was to create food and - especially drink, that achieved the difficult (to Bacon's mind) task of being both very refined and losing all its bitterness. In Bacon's terms, these generated 'roscid' (fatty) juices in the body, which conduced to longevity. And the best way to make them was to keep them a long time. ${ }^{59}$ This is exactly what the aged drinks in the New Atlantis achieve. They are of such 'thin parts' that they can pass from one side of the hand to the other. But they are not bitter: there is no 'biting, sharpness, or fretting' (483). In his other works, Bacon even suggested the kinds of 'simples' from which such drinks might be made: elder-flowers, dwarf-pine, or peony. ${ }^{60}$ In Bensalem, no doubt, the ingredients are different (483). But whatever they are made from, these drinks are masterpieces of the 'subtlety' that Bacon sought to uncover and exploit in nature. ${ }^{6 \mathrm{r}}$ 


\section{Theory and institutions}

Many of the experiments in Salomon's House, then, have their origins in different forms of late Renaissance natural knowledge. The mines, optical experiments, furnaces and pools of the New Atlantis all have some counterpart in investigations of the natural world contemporary with Bacon. And, as we have seen, the 'works' of the natural magic tradition and the preoccupations of Renaissance medicine also have an important part to play in understanding the natural science of the New Atlantis. So far, however, most of this discussion has concentrated on the 'Preparations and Instruments' of Salomon's House (480). We have not said anything about the 'employments and offices' of its fellows - the 'Depredators', 'Mystery-men', 'Compilers', and 'Interpreters of Nature' (486-7). But these offices are no less important in understanding how the New Atlantis relates to Bacon's other writings, and to contemporary institutions of natural knowledge, than the experiments they perform. For Bacon's New Atlantis shares with other Renaissance utopias a fascination with the educational institutions, as well as the raw knowledge, of society. ${ }^{62}$

The relationship between knowledge and institutions in the New Atlantis is very close. There seems little doubt that the 'employments and offices' (486-7) of the fellows of Salomon's House are the institutional embodiment of the 'art of discovery' laid out in Bacon's theoretical works. ${ }^{63}$ The three 'Depredators', who 'collect the experiments which are in all books', seem to be engaged in gathering what in the Latin Advancement Bacon calls 'learned experience' (experientia literata). ${ }^{64}$ The 'Pioners or Miners' who 'try new experiments, such as themselves think good', are performing the first stage in the process of discovery laid down in the Novum Organum: preparing the 'Natural and Experimental history' that is the foundation of everything that follows. The 'Compilers', who draw experiments 'into titles and tables, to give the better light for the drawing of observations and axioms out of them' are likewise carrying out the next stage of investigation in the Novum Organum: forming the 'Tables and Coordinations of Instances' that arrange the information in the natural history. ${ }^{65}$ The 'Dowry-men or Benefactors' seem to relate to the task, which 
Bacon never fully explained in the unfinished Novum Organum, of 'Leading forth to Practice, or to that which relates to men'. ${ }^{66}$ The 'Lamps', who 'direct new experiments' developed from the ones already conducted (487), are 'deducing or deriving new experiments from the axioms' generated by their fellows. ${ }^{67}$ Finally, and most importantly, there are the three 'Interpreters of Nature'. The interpretation of nature was one of Bacon's most longstanding preoccupations. It is the ultimate goal of the Novum Organum, the process that will finally replace the Aristotelian conception of science. ${ }^{68}$ The interpreters of nature are those who arrive at the higher goal of philosophical understanding: they 'raise' the discoveries made by all the other fellows into 'greater observations, axioms, and aphorisms' (487). In a broad sense this was the task of the entire book II of the Novum Organum - and of all the previous works Bacon had written on the question. ${ }^{69}$ In a narrower sense, the production of axioms that proceeded from sensory particulars to highest metaphysical generality was, according to the Novum Organum, the only genuine way to discover truth. $7^{0}$ Unlike the Renaissance universities, which Bacon stigmatised as slaves to Aristotle and verbal disputation, Salomon's House is an institution for the systematic and fruitful production of natural knowledge in the form of works.

\section{Technology and magic}

The New Atlantis recounts an imaginary voyage to an advanced and indeed in some sense ideal civilisation. Bacon wrote the 'fable' conscious that the world was still an imperfectly known and unexplored place. In this sense it is a work, not of colonialism, but of precolonialism. ${ }^{71}$ Instead of the historical actuality of Europeans travelling to and defeating, converting, or otherwise overwhelming the indigenous peoples of the New World, the New Atlantis presents an account of a much more advanced society. The New Atlantans are superior to their European visitors in terms of material wealth, medicine, technology, and learning generally; they are also chaster and religiously much more peaceable (477). Furthermore, one of the reasons for the success of the Bensalemites in the realm of natural knowledge is that they have successfully remembered their past. They know far more about 
the world's ancient history - about the first Atlantis, America, and about ancient Europe - than is recorded in European records. For Bacon, who in the Wisdom of the Ancients (De sapientia veterum, I6o9) interpreted the fragmentary knowledge of earliest Greek myth in terms of a lost system of natural knowledge, and who entitled his final programme of natural investigation the 'Great Renewal' (Instauratio magna), this is a positive qualification. ${ }^{72}$

We have seen how many of Bacon's preoccupations in the New Atlantis derive from earlier traditions of natural knowledge - dietetics, medicine, mechanics, alchemy, natural magic. But we must end by acknowledging that, in comparison with most of these books, the New Atlantis is ultimately a powerfully imaginative work. This may not immediately appear from the abrupt lists of inventions and achievements given by the Father of Salomon's House. But if we compare, for instance, the accounts of the food and drink in the New Atlantis with their parallel descriptions in a work like Tobias Venner's Right Road to a Long Life, it becomes clearer what Bacon has done. He has taken a common preoccupation of his time - such as dietetics; removed all the circumstances that make it familiar - like the names of plants or animals; and let his imagination develop the possibilities of what might be achieved in an appropriately constituted institution working with unlimited resources. Whereas contemporary treatises on health, and even books of secrets, are concerned precisely with things that are known - that can be described and named - Bacon uses the New Atlantis to imagine the possibilities of a place, and an institution, where the intellectual and physical materials are both quite new. In the New Atlantis, Bacon was unconstrained by the need to remain in the realm of fact, or to offer explanations and causes - imperatives that govern all his other writings on nature. William Rawley claimed that Bacon said of the Sylva Sylvarum that there was 'nothing of imagination' in it. ${ }^{73}$ The New Atlantis was published with the Sylva and has much in common with it, but in this respect they differ: the New Atlantis has much of imagination in it. Bacon's 'fable' does not merely select striking 'tricks' from various earlier traditions of natural knowledge. Rather, from a starting point in these traditions, Bacon takes the opporunity to trump them at every turn. 
A well-known science-fiction writer of the twentieth century has written that 'any sufficiently advanced technology is indistinguishable from magic. ${ }^{\prime 74}$ If any early-modern work can legitimately be called science fiction, then perhaps Bacon's New Atlantis can, with its voyage into a technically advanced society that is futuristic partly by virtue of being very old. But Bacon's New Atlantis looks back to sixteenth-century traditions like natural magic as much as it looks forward to the control over nature achieved in later centuries.

\section{Notes}

I am most grateful to Kristine Haugen, Heikki Mikkeli, Graham Rees, Nancy Siraisi, Andrew Sparling, the participants of the 25. Internationaler Wolfenbütteler Sommerkursus on 'Learned Medicine in the Late Renaissance' for their various helpful contributions to this essay.

I Francis Bacon, New Atlantis, in Brian Vickers (ed.), Francis Bacon: A Critical Edition of the Major Works (Oxford, Oxford University Press, I996), pp. 457-89 (pp. 480, 48I). All subsequent references to the New Atlantis are to this edition and are given in parentheses in the text.

2 On Bacon's posthumous reception, see Antonio Pérez-Ramos, 'Bacon's legacy', in Markku Peltonen (ed.), The Cambridge Companion to Bacon (Cambridge, Cambridge University Press, I996), pp. 3 I I-34.

3 Andrew Cunningham and Perry Williams, "De-centring the "big picture": The Origins of Modern Science and the modern origins of science', British Journal for the History of Science, 26 (I993), 407-32.

4 Denise Albanese, 'The New Atlantis and the uses of utopia', English Literary History, 57 (I990), 503-28 (p. 506).

5 David Renaker, 'A miracle of engineering: the conversion of Bensalem in Francis Bacon's New Atlantis', Studies in Philology, 87 (I990), I8I-93 (p. I82). See also Anthony F. C. Wallace, The Social Context of Innovation: Bureaucrats, Families and Heroes in the Early Industrial Revolution, as Foreseen in Bacon's 'New Atlantis' (Princeton, Princeton University Press, I982); Robert K. Faulkner, Francis Bacon and the Project of Progress (Lanham, MD: Rowman \& Littlefield, I993).

6 Rosalie L. Colie, 'Some paradoxes in the language of things', in J. A. Mazzeo (ed.), Reason and the Imagination: Studies in the History of Ideas I6oo-I80o (New York, Columbia University Press, i962), pp. 93-128 (pp. 94-5).

7 Antonio Pérez-Ramos, Francis Bacon's Idea of Science and the Maker's Knowledge Tradition (Oxford, Clarendon Press, I988).

8 See further Nicholas Jardine, 'Epistemology of the sciences', in Charles B. Schmitt, Quentin Skinner, Eckhard Kessler, Jill Kraye (eds), The Cambridge 
History of Renaissance Philosophy (Cambridge, Cambridge University Press, I988), pp. 685-7II; Peter Dear, 'Jesuit mathematical science and the reconstitution of experience in the early seventeenth century', Studies in History and Philosophy of Science, I8 (1987), I33-75.

9 Bacon, Distributio operis, in The Works of Francis Bacon, ed. James Spedding, Robert Leslie Ellis, and Douglas Denon Heath, 7 vols (London, Longman, I857), vol. I, I36: 'At nos demonstrationem per syllogismum rejicimus, quod confusius agat, et naturam emittat e manibus' (But we reject demonstration by syllogism, which hunts too erratically, and lets nature slip out of its hands).

Io Bacon, Novum Organum, in Works, I, I57 (I. 5).

I I Rosalie L. Colie, 'Cornelis Drebbel and Salomon de Caus: two Jacobean models for Salomon's House', Huntington Library Quarterly, I 8 (I954-55), 245-69. On Bacon's relations to Drebbel see further Graham Rees, 'Introduction', to Francis Bacon, Philosophical Studies c.I6II-c.I6I9, ed. Rees, The Oxford Francis Bacon VI (Oxford, Clarendon Press, 1996), pp. xvii-cx (p. xxvii) and Rees, 'Commentary on Historia densi \& rari', in Bacon, The Instauratio Magna: Last writings, ed. Rees, The Oxford Francis Bacon XIII (Oxford, Clarendon Press, 2000), pp. 269-304 (pp. 301, 303-4). The English mathematician John Napier had also proposed building 'devices of sailing under the water' in 1596 (New Atlantis, ed. Vickers, p. 8oo; note to p. 486 ).

I2 J. Peter Zetterberg, 'Echoes of nature in Salomon's House', Journal of the History of Ideas, 43 (I982), I79-93 (p. I89).

I3 Bacon, Novum Organum, in Works, I, I57 (I. 3): 'Natura enim non nisi parendo vincitur' (for nature is not conquered unless it is obeyed).

I4 Penelope Gouk, Music, Science and Natural Magic in Seventeenth-Century England (New Haven, Yale University Press, 1999), pp. 32, I59; Zetterberg, 'Echoes', p. I90; Salomon de Caus, Les Raisons des forces mouvantes (Frankfurt, Jan Norton, I6I5).

I5 Hieronymus Fabricius ab Aquapendente, De brutorum loquela (Padua, Laurentius Pasquatius, I603). Francis Bacon, Sylva Sylvarum: or a Natural History [1627], in Works, II, 4I3 (\$200). See further Zetterberg, 'Echoes', p. Igo.

I6 William Eamon, Science and the Secrets of Nature: Books of Secrets in Medieval and Early Modern Culture (Princeton, Princeton University Press, I996), pp. 290-I.

I7 For further discussion of this question, see Brian Vickers, 'Bacon's socalled "Utilitarianism": sources and influence', in M. Fattori (ed.), Francis Bacon: Terminologia e Fortuna nel XVII Secolo (Rome, Edizioni dell'Ateneo, I984), pp. 28I-3I4.

I 8 Virgil K. Whitaker, 'Francis Bacon's intellectual milieu', in Brian Vickers (ed.), Essential Articles for the Study of Francis Bacon (Hamden, CT, Archon, I968), pp. 28-50 (pp. 30-I). 
I9 Andrew Cunningham, 'Getting the game right: some plain words on the identity and invention of science', Studies in History and Philosophy of Science, I9 (1988), 365-89.

20 For Bacon's views on this point, see Novum Organum, in Works, I, 365 (2. 52).

2I For the distinction between demonic and natural magic, see Giovan Battista della Porta, Magiae naturalis libri viginti (Frankfurt, Apud Andreae Wecheli heredes, I59I), p. 2 (I. 2), and further D. P. Walker, Spiritual and Demonic Magic from Ficino to Campanella (London, Warburg Insitute, I958).

22 Francis Bacon, The Advancement of Learning [1605], Michael Kiernan (ed.), The Oxford Francis Bacon IV (Oxford, Clarendon Press, 2000), p. 89.

23 See Heinrich Cornelius Agrippa, De incertitudine \& vanitate scientiarum \& artium atque excellentia verbi Dei declamatio (Antwerp, Joannes Grapheus, I530), sig. $\mathrm{N}_{4}{ }^{\text {; }}$ d della Porta, Magia naturalis, pp. 2-3 (I. 2). See further Wayne Shumaker, Natural Magic and Modern Science: Four treatises I590I657 (Binghamton, NY, Medieval \& Renaissance Texts \& Studies, I989), p. I7; Brian P. Copenhaver, 'Natural magic, hermeticism, and occultism in early modern science', in David C. Lindburg and Robert S. Westman (eds), Reappraisals of the Scientific Revolution (Cambridge, Cambridge University Press, I990), pp. 26I-302 (pp. 280-I).

24 On the importance of della Porta for the Sylva, see Robert Leslie Ellis, 'Preface to the Sylva Sylvarum', in Bacon, Works, II, 326, 328; Rees, 'An unpublished manuscript', pp. 389, 408, who notes that sixty-two experiments in the Sylva are taken from the Magia naturalis, which Bacon read the Frankfurt edition of I59I; Rees, 'Bacon's Sylva Sylvarum: prelude to remarks on the influence of the Magia naturalis', in E. Garin (ed.), Giovan Battista della Porta nell'Europa del suo tempo (Naples, Guida, I99I), pp. $26 \mathrm{I}-72$.

25 An exception is the excellent study by Paolo Rossi, Francis Bacon: From Magic to Science, trans. Sacha Rabinovitch (London, Routledge and Kegan Paul, I968), Chapter I, although Rossi ultimately separates Bacon sharply from the Renaissance magical tradition.

26 Bacon, Sylva, in Works, II, 378 (\$93), and compare ibid. II, 663 (\$969). See further Rees, 'Bacon's Sylva Sylvarum', p. 270.

27 Lorraine Daston and Katherine Park, Wonders and the Order of Nature I I50-I750 (New York, Zone, I998).

28 Meric Casaubon, Generall Learning: A Seventeenth-Century Treatise on the Formation of the General Scholar, ed. Richard Serjeantson (Cambridge, RTM, I999), p. I8I. See also Zetterberg, 'Echoes', p. I9I.

29 On this point see also Renaker, 'A miracle', p. I9I.

30 But see Ian Box, 'Medicine and medical imagery in Bacon's Great Instauration', Historical Reflections/Réflexions historiques, I6 (I989), 35 I-65.

3I On this and further suggestive parallels between Bensalem and Venice, see Michèle Le Doeuff, 'Introduction', to Francis Bacon, La Nouvelle Atlantide, 
trans. Michèle Le Doeuff and Margaret Llasera (Paris, GF-Flammarion, I995), pp. 7-75 (pp. 46-7); also Wallace, Social Context of Innovation, pp. 28-3I.

32 On the ancient and Renaissance background to theories of infectious disease, see Nancy Siraisi, Medieval and Early Renaissance Medicine: An Introduction to Knowledge and Practice (Chicago, University of Chicago Press, I990), pp. I28-30; Vivian Nutton, 'The seeds of disease: an explanation of contagion and infection from the Greeks to the Renaissance', Medical History, 27 (I983), I-34; Nutton, 'The reception of Fracastoro's theory of contagion: the seed that fell among thorns?', Osiris, 6 (I990), I96-234.

33 Although Bacon elsewhere argues that many medicines mean few cures: Historia vitae, in Works, II, I92 (trans. V, 300).

34 Bacon elsewhere manifests an interest in discovering what parts of animals are essential for life: Sylva, in Works, II, 474 (\$40o); Historia vitae, in Works, II, 208-9 (trans. V, 316); 'Historia \& inquisitio de animato \& inanimato', in Instauratio Magna: Last Writings, pp. 227-35; see also De augmentis, in Works, I, 593-4 (trans. IV, 386).

35 Richard Palmer, 'Health, hygiene and longevity in medieval and Renaissance Europe', in Y. Kawakita, S. Sakai and Y. Otsuka (eds), History of Hygiene (Tokyo, Ishiyaku EuroAmerica, I991), pp. 75-98 (p. 8o).

36 Richard Palmer, "'In this our lightye and learned tyme": Italian baths in the era of the Renaissance', in R. S. Porter (ed.), The Medical History of Waters and Spas (London, Wellcome Institute for the History of Medicine, I990), pp. I4-22; Bacon, Advancement, pp. IoI-2.

37 Andrew Cunningham, "Fabricius and the "Aristotle project" in anatomical teaching and research at Padua', in A. Wear, R. K. French and I. M. Lonie (eds), The Medical Renaissance of the Sixteenth Century (Cambridge, Cambridge University Press, I985), pp. 195-222; see also Bacon, Advancement, pp. 99-100.

38 See further Heikki Mikkeli, Hygiene in the Early Modern Tradition (Helsinki, Academia Scientiarum Fennica, I999), esp. pp. 32-40.

39 Bacon, De augmentis, in Works, I, 598 (4. 2) (trans. IV, 290); Bacon, Historia vitae, in Works, II, I03, I 55 (trans. V, 215, 263). Bacon was in fact repeating a common accusation that learned physicians made against 'empirics' at the time: see Harold J. Cook, 'The new philosophy and medicine in seventeenth-century England', in David Lindberg and Robert S. Westman (eds), Reappraisals of the Scientific Revolution (Cambridge, Cambridge University Press, I990) pp. 397-436 (pp. 409-1o).

40 On Zerbi, see Mikkeli, Hygiene, p. 77; on Venner, Andrew Wear, 'Epistemology and learned medicine in early modern England', in Knowledge and the Scholarly Medical Traditions (Cambridge, Cambridge University Press, I995), pp. I5I-73 (pp. I56-9). Despite its title, Venner's book is in English.

4I Keith Thomas, Religion and the Decline of Magic: Studies in Popular Beliefs in Sixteenth and Seventeenth Century England (London, Weidenfeld and Nicolson, I97I), pp. 2 I-2. 
42 Their food and drink are not, then, just tokens of Bensalemite 'consumerism', as is argued by Robert P. Adams, 'The social responsibilities of science in the Utopia, New Atlantis and after', Journal of the History of Ideas, Io (1949), 374-98 (p. 387).

43 See Historia vitae, especially at Works, II, I57-8 (trans. V, 265-6).

44 Bacon, 'The Grains of Youth', in Works, III, 827-9. Methusalah, the oldest person in the Bible, lived to 969 .

45 Francis Bacon, 'De vijs mortis', in Philosophical Studies c.I6II-C.I6I9, pp. 269-359.

46 Bacon, Advancement, pp. 99-I02; Bacon De augmentis, in Works, I, 586602 (trans. IV, 379-94).

47 Bacon, De augmentis scientiarum, in Works, I, 598-602 (4. 2): 'nova est, et desideratur; estque omnium nobilissima' (p. 598). On this passage see Mikkeli, Hygiene, p. 79, and further on Bacon's theories of prolongation, Rees, 'Introduction', to Bacon, Philosophical Studies c.I6II-c.I6I9, pp. lxv-lxix.

48 Nancy G. Siraisi, The Clock and the Mirror: Girolamo Cardano and Renaissance Medicine (Princeton, Princeton University Press, 1997), p. 78; Michela Pereira, 'Un tesoro inestimabile: elixir e "prolongatio vitae" nel l'alchimia del '30o', Micrologus, I (1993), I6I-87.

49 Palmer, 'Health', p. 88. Bacon, Historia vitae, in Works, II, I57; Bacon, De augmentis, in Works, I, 599 (trans. IV, 39I).

50 Laurent Joubert, Popular Errors [1578], trans. Gregory David de Rocher (Tuscaloosa, University of Alabama Press, I989), p. 4I. Thomas S. Hall, 'Life, death and the radical moisture', Clio medica, 6 (I97I), 3-23 (esp. p. I5). Bacon, Historia vitae, in Works, II, 105-6, I58. Later commentators took issue with Bacon on this: see Bacon, Historia vitae et mortis cum annotationibus Barthol[omei] Moseri (Dillingen, Typis academiae, I645), pp. 7-9.

5I Palmer, 'Health', pp. 87-9I; Mikkeli, Hygiene, pp. 73-9.

52 Marsilio Ficino, Three Books on Life, ed. and trans. Carol V. Kaske and John R. Clark (Tempe, AZ, Medieval \& Renaissance Texts \& Studies, I998), pp. I96-9 (2. I I): 'volentis, inquam, adolescentis, sani, laeti, temperati, cui sanguis quidem sit optimus, sed forte nimius' (a youth, I say, who is willing, healthy, happy, and temperate, whose blood is of the best but perhaps too abundant). Bacon, Sylva, in Works, II, 625 (\$859); Historia vitae, in Works, II, I99 (trans. V, 307).

53 Bacon, Sylva, in Works, II, 555 (\$692).

54 Bacon, Historia vitae, in Works, II, I95 (trans. V, 302); ibid., II, I09, I53 (trans. V, 22I, 26I); ibid. II, 224: 'Curatio morborum temporariis eget medicinis; at longaevitas vitae expectenda est a diaetis'; ibid., II, I59 (qualifies Cornaro). On Cornaro, see Palmer, 'Health', pp. 90-5; Mikkeli, Hygiene, pp. 86-92.

55 Bacon, De augmentis, in Works, I, 602 (trans. IV, 394). 
56 Bacon, Historia vitae, in Works, II, I54 (trans. V, 262); ibid., II, I 49 (trans. V, 257); ibid., II, I35, I42, I 59, I 75 (trans. V, 246, 25I, 266, 283); ibid., II, I54, I 72 (trans. V, 263, 280).

57 Bacon, Historia vitae, in Works, II, I09, I I 5-I6 (trans. V, 222, 227-8).

58 Rees, 'An unpublished manuscript', p. 402: ('preseruat. of Herbs' and 'Trialls for the Conseruatory of Snowe'); Bacon, Sylva, in Works, II, 445-50 (§§312-26); Bacon, Historia vitae, in Works, II, I I6-18 (trans. V, 228-9). Lisa Jardine and Alan Stewart, Hostage to Fortune: The Troubled Life of Francis Bacon (London, Gollancz, I998), pp. 502-3.

59 Bacon, Historia vitae, in Works, II, 22 I (trans. V, 330); ibid., II, I 85 (trans. V, 292-3). See further Bacon, Sylva, in Works, II, 555 (\$692).

60 Bacon, Sylva, in Works, II, 555 (§692). Compare Bacon, Historia vitae, in Works, II, I86 (trans. V, 293).

6I Graham Rees, 'Atomism and "subtlety" in Francis Bacon's philosophy', Annals of Science, 37 (1980), 549-7I.

62 Compare Tommaso Campanella, La Città del sole: dialogo poetico / The City of the Sun: A poetical dialogue [1623], trans. Daniel J. Donno (Berkeley, University of California Press, I98I), esp. pp. 92-7; Johann Valentin Andreae, Christianopolis, trans. Edward H. Thompson (Dordrecht, Kluwer, I999), esp. pp. I86-257; and see further Michèle Le Doeuff, 'Utopias: scholarly', Social Research, 49 (I982), 44I-66.

63 As Brian Vickers' note on the 'Compilers' suggests (800). Compare with Julian Martin, Francis Bacon, the State and the Reform of Natural Philosophy (Cambridge, Cambridge University Press, I992), pp. I68-9; Wallace, Social Context of Innovation, pp. 16-18.

64 Bacon, De augmentis, in Works, I, 622-33 (5. 2) (trans. IV, 4I3-2 I).

65 Bacon, Novum Organum, in Works, I, 236 (2. Io): 'Historia ... Naturalis et Experimentalis', 'Tabulae et Coordinationes Instantiarum'.

66 Bacon, Novum Organum, in Works, I, 268 (2. 2 I): 'Dicemus itaque ... de Deductione ad Praxin, sive de eo quod est in ordine ad Hominem'.

67 Bacon, Novum Organum, in Works, I, 235 (2. Io): 'deducendis aut derivandis experimentis novis ab axiomatibus'.

68 See further Lisa Jardine, Francis Bacon: Discovery and the Art of Discourse (Cambridge, Cambridge University Press, I974); Jean Marie Pousseur, 'De l'interpretation: une logique pour l'invention', La revue internationale de philosophie, 40 (I986), 378-98.

69 Bacon, Valerius Terminus of the Interpretation of Nature, in Works, III, I99252; De interpretatione naturae proœmium, in Works, III, 5I 8-20; Delineatio et argumentum, in Works, III, 547-57; De interpretatione naturae sententiae xii, in Works, III, 783-8; Novum Organum, sive indicia vera de interpretatione naturae, in Works, I, 70-365.

70 Bacon, Novum Organum, in Works, I, I59 (I. Io); cf. the final stage of interpretation in ibid., I, 268 (2. 2I). 
7 I On the New Atlantis as a 'colonialist' document, see Charles C. Whitney, 'Merchants of light: science as colonization in New Atlantis', in William A. Sessions (ed.), Francis Bacon's Legacy of Texts: 'The Art of Discovery Grows with Discovery' (New York, AMS, I99o), pp. 255-68; Amy Boesky, 'Bacon's New Atlantis and the laboratory of prose', in Elizabeth Fowler and Roland Greene (eds), The Project of Prose in Early Modern Europe and the New World (Cambridge, Cambridge University Press, 1997), pp. I38-53 (p. I4I); and Albanese, 'New Atlantis'.

72 Francis Bacon, De sapientia veterum (London, I6og). See further Robert Ginsberg, 'Francis Bacon's De sapientia veterum: interpretation and insight', in Acta Conventus Neo-Latini Turonensis, 2 vols, ed. Jean-Claude Margolin (Paris, Vrin, I980), pp. 229-35. On 'Renewal' as the best translation of Instauratio, see Lisa Jardine, 'Introduction', to Bacon, The New Organon, Jardine (ed.), trans. Michael Silverthorne (Cambridge, Cambridge University Press, 200o), pp. vii-xxviii (p. xiii).

73 William Rawley, 'To the reader', in Bacon, Sylva, in Works, II, 337. See further Michèle Le Doeuff, 'Un rationaliste chez Augias: de la force de l'imagination dans la Sylva Sylvarum', Les Études philosophiques, 3 (1985), 325-34.

74 Arthur C. Clarke, 'Hazards of prophecy: the failure of imagination' [1962], in Profiles of the Future (New York, Holt, Rinehart, and Winston, 1984), p. 26 ('Clarke's Third Law'). 